\title{
Desemantization of Functional Grammatical Causatives in the Aspect of Grammaticalization
}

\author{
Svetlana V. Shustova - Elena A. Osheva - Konstantin A. Klochko
}

\section{DOI: $10.18355 /$ XL.2017.10.01.04}

\begin{abstract}
This article dwells upon the issues, connected with the prototype theory and grammaticalization theory in the sphere of causativeness category which is considered as interpersonal interaction. Functional grammatical causatives appear to be a means of causativeness actualization. In the process of functioning, they display prototypical characteristics which form the core of causativeness category and are traced to analytical tools of a language. One of leading grammaticalization indicators is desemantization, as a verb loses its lexical meaning in a certain environment and acquires grammatical functions. Functional grammatical causatives are considered to be analytical causative, for their meaning is formed in the sphere of functioning of such English verbs as to cause, to make, to force, to get, to bring, to let, to permit, to set, to keep, to allow; German verbs: lassen (to let, to cause), heißen (to tell, to bid), machen (to make), bringen (to make, to get, to drive). Functional grammatical causatives possess generalized meaning and desemantization, display high usage frequency and have a wide range of generated constructions.

Key words: desemantization, grammaticalization, functional grammatical causative, causativeness, prototypical causation, transcategorization, analytical tool, German, English, prototypical means
\end{abstract}

\section{Introduction}

The subsystem of causativeness in the sphere of causation is seen by the authors as a universal subcategory. This category can obtain different expressions in different languages. The ways of expressing the meaning of causativeness in German and English mainly coincide, which clearly follows from their belonging to the same language group: Indo-European languages, German branch, West-German group. For instance, in the languages of the Indians there is a domination of morphological means and verb incorporations, while in Hindi, Urdu, Gujarati, and Rajasthani languages the morphological and phonetic means of forming the causative meaning are more frequent. In the Burmese language, causative is formed by using the direct object; in African languages, causative is expressed through a number of causative means (Khoisan, Bantu, Atlantic languages, Gur languages). In the Lingala language (Congo), Kikongo (Bantu languages) morphological causative is also present. Lexical-syntactical causative is detected in the Sango language which is referred to Ubangi languages. The data for study was taken from dictionaries by the means of overall sampling and from the corpora of the English language by the means of overall and selective sampling, in particular, the Corpus of Contemporary American English, created by the team of Brigham Young University and the Corpora database of Leipzig University (Germany).

\section{Methods}

The choice of analysis methods was determined by the aim of the study, as well as the specifics of the research target. To examine desemantization of functional grammatical causatives in the aspect of grammaticalization, we used methods of seme analysis, context analysis, interpretation, and complex functional analysis. 


\section{Study Findings}

Grammaticalization is a process in which grammar elements that appear in the process of desemantization obtain new grammatical functions. According to this, it is possible to say that due to desemantization, the functional (grammatical) meaning emerges instead of the diminished lexical one. Thus, we reckon that the category of causativeness could be a target of precise interest in the fields of language philosophy, grammar philosophy, and psycholinguistics - as it is a perfect piece of data for the studies of grammaticalization process issues, taking functional grammatical causatives as an example. These issues are connected with the process of decoding of the causator's intention by the object of causation, differentiation between the types of causation and the interpretation of relations between events and actions as well.

\section{Discussion}

In the given article we will dwell upon the problem of verb desemantization (semantische Ausbleichung, semantic bleaching) (Szczepaniak, 2011: 11) in the aspect of grammaticalization on the example of causative constructions, formed by analytical causative. Words in different languages do not have the same range of meaning $\langle\ldots>$ By means of language we communicate what is special in our view of things, for, he says (W. V. Humboldt) words come into being to present this view. They are not a direct reflection of the object as such but of the picture which this object has conjured up in the soul (New Trends: 191).

Chr. Lehmann, acknowledging Kurylowicz (1965), says: "Under the diachronic aspect, grammaticalization is a process which turns lexemes into grammatical formatives and makes grammatical formatives still more grammatical..." (Lehmann 1985, p. 303). B. Heine and M. Reh define grammaticalization: “... as evolution whereby linguistic units lose in semantic complexity, pragmatic significance, syntactic freedom, and phonetic substance..." (Heine, Reh, 1984: 15). E.C. Traugott and B. Heine underline: “... grammaticalization $<\ldots>$ refers to that part of the theory of language that focuses on the interdependence of language and parole, of the categorical and less categorical, of the fixed and the less fixed in language. Grammaticalization is the linguistic process, both through time and synchronically, of organization of categories and of coding" (Traugott, Heine, 1991: 1); “...grammaticalization is a kind of language change, subject to certain general processes and mechanisms of change. $<\ldots>$ Much of the literature on unidirectionality characterizes the development of grammatical from lexical meaning in terms of desemantization, bleaching and emptying or loss of semantic or pragmatic meaning" (Traugott, Heine, 1991: 3, 4). This approach correlates with the position of T.A. Maisak who treats grammaticalization as a special semantic process which results in the emergence of a language unit with grammatical meaning (Maisak, 2005: 40).

One of leading grammaticalization indicators is desemantization - when a verb loses its lexical meaning in a certain environment and acquires grammatical functions. Grammaticalization "displays a certain degree of change in the categorical meaning of a verb, its transcategorization as a language unit which reflects its movement across categorical continuum from lexical to grammatical meaning. The more grammatical characteristics the verb acquires, the less specific its lexical meaning becomes" (Boldyrev, 2009: 90).

An analytical causative appears to be a prototypical means of actualizing the meaning of causativeness. According to G. Lakoff, the categories of causation types can also show prototypical effects. Prototypical causation is represented in Lakoff's concept as a cluster of interaction features and actualizes direct interaction. Prototypical causation appears to be direct manipulation which is characterized most typically by the following cluster of interactional properties: 1 . There is an agent that does something. 2. There is a patient that undergoes a change to a new state. 3 . 
Properties 1 and 2 constitute a single event; they overlap in time and space; the agent comes in contact with the patient. 4. Part of what the agent does (either the motion or the exercise of will) precedes the change in the patient. 5. The agent is the energy source; the patient is the energy goal; there is a transfer of energy from agent to patient. 6 . There is a single definite agent and a single definite patient. 7. The agent is human. 8. a. The agent wills his action. b. The agent is in control of his action. c. The agent bears primary responsibility for both his action and the change. 9. The agent uses his hands, body, or some instrument. 10. The agent is looking at the patient, the change in the patient is perceptible, and the agent perceives the change (Lakoff, 1990: 54-55).

While analyzing direct and indirect causation, G. Lakoff points out that unintentional causation is represented in a weaker degree than the deliberate one. He also points out the following rule: the more unintentional the causation is, the closer to each other the morphemes expressing cause and result are. E.g. kill expresses direct causation and both cause and result in one morpheme; cause to die expresses indirect causation.

Functional grammatical causatives are considered as lexical-syntactical analytical causatives, for their meaning is formed in the sphere of functioning of such English verbs as to cause, to make, to force, to get, to bring, to let, to permit, to set, to keep, to allow, etc.: ... she was at once thrown into a state of selfish panic which caused her to become completely oblivious; I made him work. I made him angry; I got him to work. I let him go. I brought him to ruin (Silnitsky, 2006, V. 2, p. 23; V. 1, p. 192); She wanted to go, but her parents wouldn't let her; I'm letting you stay up late, just this once; Don't let it worry you; If he needs money, let him (=he should) earn it (Cambridge Advanced Learner's Dictionary, 2005, 2006).

In German, the following verbs can be traced to such causatives: lassen (to let, to cause), heißen (to tell, to bid), machen (to make), bringen (to make, to get, to drive), etc.:

lassen (to let, to cause): jmdn. etw. wissen lassen (let sb. know smth.); jmnd. etw. tun lassen (let sb. do smth.); jmnd. in dem Glauben lasswn, dass ... (let smb. think that ...) (Duden. Oxford, 2005);

heißen (to tell, to bid): jmnd. etw. tun heißen (tell sb. to do smth.; bid sb. to do smth.) (Duden. Oxford, 2005);

machen (to make): jmnd. glücklich/ eifersüchtig machen (make sb. happy/ jealous); jmnd. lichen/ weinen/ leiden machen (make sb. laugh/ cry/ suffer) (Duden. Oxford, 2005);

bringen (to make, to get, to drive): jmnd. zum Lachen/ zur Verzweiflung bringen (make smb. laugh/ drive smb. to despair); jmnd. dazu bringen, etw. zu tun (get smb. to do smth.) (Duden. Oxford, 2005).

For instance, W. Hüllen considers auxiliary causatives in terms of analytical verb phrases containing like, make, have, get. E.g.: let (us) go, (the court) make(s) (bussing) legal, (Mary) had (John) come (to the meeting), get (the thing) done; veranlassen (antreiben) (to cause, to induce (to drive), (bekannt) machen (to announce smth.) (Hüllen, 1982: 170-177):

veranlassen (antreiben) (to cause, to induce (to drive): Was hat dich zu diesem Schritt/ dieser Bemerkung varanlasst? (What caused or led you to take this step/ make this remark?) (Duden. Oxford, 2005);

antreiben (to drive): jmnd. (dazu) antreiben, etw. zu tun (drive sb. to do sth.) (Duden. Oxford, 2005).

Our approach to functional grammatical causatives corresponds to that of M. Baker's concept of complementizers (auxiliary verbs of tense/mood). He refers to complementizers such words as that, if, whether, for, as well as auxiliary verbs will, would, may, might, can, could, shall, should, must, have, be. He calls them minor 
categories, mentioning that they are connected with major categories (noun, verb, adjective) only semantically (Baker, 2001: 33-34). We share this point of view and reckon that in the aspect of grammaticalization in the sphere of the causative, the additional prototypical "minor categories" which modify context meaning can be pointed out. In English it will be the following verbs: to cause, to make, to force, to get, to bring, to let, to permit, to set, to keep, to allow; in German - lassen, heißen, machen, bringen, fordern, zwingen, empfehlen, anregen, anbieten, raten (to let, to tell, to bid, to make, to get, to drive, to demand, to force, to recommend, to prompt, to advise) and their synonyms. M. Baker considers these words from minor categories as the "peak of the formed groups" (Baker, 2001: 34). The examples wir lassen nachdenken (we let/cause to think), wir zwingen nachzudenken (we force to think), wir fordern nachzudenken (we advise to think), wir empfehlen nachzudenken (we demand to think) display such semantic disposition of the situation which is different in the actualization of intensity of affecting the object of causation. Regarding the fact that functional grammatical causatives show the signs of desemantization, they become the auxiliary peak of the whole causative situation and are located before the correlated verb group. In terms of valency potential, functional grammatical causatives are characterized by a tight connection with the elements of the whole syntactical environment.

The following features are attributed to functional grammatical causatives: 1) they possess a more generalized meaning than a lexical causative; 2) they are more frequent in use; 3 ) they tend to lose their lexical meaning (desemantise): 4) they have a wide range of generated constructions (Silnitsky, 2006: 22; Boldyrev, 2009: 90-95).

For example the German verb lassen (to let, to cause) apart from its free meaning "to let it be", "to leave as it is" and other similar variants has a structurally bound meaning "to allow", "to let" when two objects are added in the accusative case and the infinitive: Der Lehrer lässt die Schüler laut sprechen (The teacher made the students speak loudly / The teacher let the students speak loudly/The teacher allowed the students to speak loudly). Sometimes Infinitive constructions with lassen (to let, to cause) display such degree of abstract meaning that the verb almost loses its lexical meaning. In this case, lassen (to let, to cause) becomes an analytical means of expressing gramaticized meanings: modality, transitivity, causativeness. Meanwhile, the abstracted meaning of lassen (to let, to cause) coalesces with the concrete meaning of the Infinitive, thus changing it somehow. Analytical causative lassen (to let, to cause) + Infinitiv is a universal means of expressing causativeness: “... lassen Sie ihn doch spielen" (Kafka, 1989) (Now then let him play - Now then give him an opportunity/a chance to play) ; modality: ..., dass sie überhaupt mit ihnen nicht reden lassen durfte (Kafka, 1989) (She is not allowed/permitted to talk to them).

Causative constructions heißen (to tell, to bid) + Infinitiv express an inducement to action or changing the situation by an order: Der Schaffner hieß ihn in die Straßenbahn einsteigen (Big German-Russian Dictionary, 1980) (The farecollector let him get on the tram/ The farecollector allowed/permitted him to get on the tram). The construction machen (to make) + Infinitiv has a single meaning, which lets it to be used stressing the inducing meaning of the verb: jmnd. lachen machen (make smb. laugh).

Functional grammatical causatives group with non-finite verb forms and finite forms in the position of a secondary predicate in the Complex Object, E.g.: $I$ made him a writer (Silnitsky, 2006, V. 2, p. 22), I had him fired, I put him to ease (Silnitsky, 2006, V. 1, p. 192); machen (to make): jmnd. glücklich/ eifersüchtig machen (make sb. happy/ jealous); jmnd. lichen/ weinen/leiden machen (make smb. laugh/cry/suffer) (Duden. Oxford, 2005).

The combinations of functional grammatical causatives with the Infinitive are considered as special analytical forms (isolating analytical causatives) (Symulov, 
2006: 34). There is no common way of forming a grammatical causative in English and German. The meaning of causation is given to the lexical verb by functional grammatical causatives which actualize additional shade of inducement in the causative construction with a lexical verb. In English and German causation is also indicated by the direct object after the intransitive verb. In such cases, this verb becomes transitive. Thus, causation is expressed by the combination of two words: an intransitive verb and a direct object. The meaning of causation is expressed by a separate lexical or functional word, that is by means of two word combinations: a) functional grammatical causatives + object + lexical verb; b) intransitive verb + direct object. Such combinations as functional grammatical causatives + object + lexical verb are analytical forms. In this case, we may mention grammar phrases, in which functional grammatical causatives are considered as a formal component of causation meaning. The general meaning of causation is expressed by a lexical verb (lexical causative or non-causative).

The difference between analytical causative functional grammatical causatives + object + lexical verb (I) and intransitive verb + direct object (II) is the following:

Causative I gives a stronger degree of causation compared to Causative II;

Causative I is formed by transitive and intransitive verbs, while Causative II - only by intransitive ones;

Causative I expresses factual and permissive causation, while Causative II only factual.

The forming of Causative I from any lexical verb is standardized, while Causative II is not.

Functional grammatical causatives E.g.: to cause, to make, to force, to get, to bring, to let, to permit, to set, to keep, to allow; lassen (to let, to cause), heißen (to tell, to bid), machen (to make), bringen (to make, to get, to drive) etc., can be as a future core of a causative structure. Functional phrases with these causatives shouldn't be considered as idioms, but as phrases where lexical and functional components can be combined just like morphemes in a word. Analytical forms are an integrative part of the causative construction, which also includes a verb as a basis of lexical meaning of the whole construction.

The unity of the whole analytical structure and the intertwining of its parts is a prominent link in the chain of arguments, proving that analytical form is a part of the morphological system of a language. Grammatical and semantical unity of the analytical form of a verb reveals only in the junction of its parts when each of them obtains a definite meaning.

On the part of syntax, grammaticalization of the verb is characterized by the reduction of its syntactic range: its valency now is focused on a definite actant. On the part of its semantics, grammaticalization changes the meaning of the verb to a greater degree of subjectivism and abstraction. The above mentioned examples of functional grammatical causatives usage describe, according to $\mathrm{N}$. Boldyrev, not the situation, but the peculiarity of its perception, assessment, and conceptualization (Boldyrev, 2009: 90).

The finite form of the verb indicates a verb-dependent status of the situation which is denoted by the second verb, acting as a predicative actant.

... fordere ich Sie auf, sich innerhalb einer Frist von sechs Monaten (...) um für Sie angemessenen Wohnraum zu bemühen'(www.wortschatz.uni-leipzig.de) (I demand you to occupy a flat during the next 6 months).

Ich befehle dir augenblicklich, mich zu lieben (www.wortschatz.unileipzig.de) (I order to love me right now).

Ich bitte, ich befehle, getreu Alles zu berichten (www.wortschatz.unileipzig.de) (I order to tell me frankly about everything) 
Functional grammatical causatives actualize causative meaning, but, unlike lexical causatives, these verbs do not specify the causative action. Functional grammatical causatives don't display the "content of causation" or the "content of causative action" in their semantic potential. This function is not implied in their semantics and emerges as a result of transcategorization which takes place due to their constant use in certain syntactical contexts. A number of types of causative constructions can be outlined for functional grammatical causatives. In these constructions the following elements ought to be present: a functional grammatical causative or/and a second verb, acting as a predicative actant (or/and a verbal noun).

It is interesting to dwell upon the peculiarities of usage of a functional grammatical causative fordern (to demand) in the German language. It is mostly used with verbal nouns acting as a predicative actant, e.g.: die Freilassung (release), die Aufklärung (solution, elucidation, explanation, resolution), die Beteiligung (participation, involvement), die Bezahlung (payment), die Festnahme (arrest), die Herausgabe (publication), die Verschärfung (intensification, increase), die Erhöhung (raising) (Duden. Oxford, 2005 ), etc.

Sie forderten die Freilassung aller politischen Gefangenen... (www.wortschatz.uni-leipzig.de) (They demanded to free all political prisoners).

Die Teilnehmer fordern zu dem die Aufklärung der Bevölkerung über mögliche Katastrophen und über Kriesenvorbeugung (www.wortschatz.unileipzig.de ) (The members claimed to inform the people about possible disasters and the dangers of crisis).

Verbal noun becomes the core of meaning when the content of causative action is actualized. The meaning of verbal nouns is very complicated because they combine the meaning of process derived from the verb and nominal meaning obtained through the derivation. In plainer words, they possess a different degree of the socalled "verbogenicity" (retaining verbal meaning) (a term by Muryasov, 1989: 50).

Transcategorization of functional grammatical causatives is based on the growing degree of abstraction and, hence, desemantization. But it is necessary to mention that the loss of lexical meaning by the verb in one grammatical function does not mean that it loses it in a different syntactical environment. According to $\mathrm{N}$. Boldyrev, one and the same verb can be either lexical or functional in different contexts.

Klar ist bis lang nur, was sie von ihm fordern: Reformen, Demokratisierung und vor allem active Bekämpfung jeglicher Gewalt (www.wortschatz.uni-leipzig.de) (It's clear what they demand him to do: reforms, democratic changes and first of all a struggle with violence) (lexical and functional meaning);

Sie fordern jetzt eine ökologische Finanzreform (www.wortschatz.unileipzig.de) (They demand an environmental financial reform) (lexical meaning);

Bei der Versammlung in Brüssel forderten mehr als 500 Teilnehmer, den Kampf gegen Feinndlichkeit zu verstärken (www.wortschatz.uni-leipzig.de) (At the meeting in Brussels 500 participants demanded to reinforce the struggle with hostility) (functional meaning).

Meanwhile, multi-categorical and multi-significant features in this phenomenon are revealed, which coincides with Lakoff's and Johnson's statement that "understanding always involves human categorization" and "categories are neither fixed nor uniform. They are defined by prototypes and family resemblances to prototypes and are adjustable in context, given various purposes. Whether a statement is true depends on whether the category employed in the statement fits, and this in turn varies with human purposes and other aspects of context" (Lakoff, Johnson, 2003: 192). 


\section{Conclusion}

Thus, grammaticalization of some verbs shows that transcategorization is not odd, but rather regular process. Lexical meanings, which acted as functional, cease to be the semantical core of the structure and are subject to the complicated process of desemantization ("bleaching"). It implies the qualitative transformation of the semantic potential of the verb to the gradual loss of meaning, i.e., semantic reduction. The suggested approach to the research of the functional grammatical causative potential specifies the notion of causativeness in general, which is especially actual for contemporary linguistic studies. The results of the survey on functional grammatical causatives functioning cannot be considered as full, in terms of the tackled notion. We consider the further inquiry into the functional potential of other types of causatives (lexical, semantical, and syntactical ones) to be very perspective in the aspect of desemantization or typology of comparative linguistics or functional grammar. Yet, the issues connected with the actualization of causativeness beyond the core field of causativeness stay undetermined.

\section{Bibliographic references}

BACH, E. 1989. Informal lectures on formal semantics. New York: State University of New York. 224 p.

BAKER, M.C. 2001. The Atoms of Language. The Mind's hidden Rules of Grammar. Basic Books: NY. 127 p.

Big German-Russian Dictionary. 1980. In 2 vol. Compliedby: E.I. Leping, N.P. Strahova, N.I. Filicheva, M.J. Zwilling, R.A. Cherfas; supervised by:O.I. Moskalskaya. 2-nd, edition, Moscow. Vol. 1. A-K. Vol. II. L-Z.

BOLDYREV, N.N. (2009) Functional categorization of the English verb. Moscow. $144 \mathrm{p}$.

BOLL, H. Der Engel schwieg. MiteinemNachwort von Werner Bellmann. 5. Auflage. Koln: Verlag Kiepenheuer\&Witsch, 1997. 213 S.

Cambridge Advanced Learner's Dictionary. 2005, 2006. Cambridge University Press. 3-rd printing.

Corpora Database of Leipzig University www.corpora.informatik.uni-leipzig.de

Duden. Oxford. Großwörterbuch Englisch. Deutsch-Englisch. Englisch-Deutsch. (2005) 3., überarbeitete und aktualisierte Auflage. Herausgegeben von der Dudenredaktion und Oxford University Press. Mannheim; Leipzig; Wien; Zürich: Dudenverlag..

HALL, R.A. 1985. Innate Capacity, Know-How and Use in Lunguage. Linguistics and Philosophy. Current Issues. In: Linguistic Theory 42. Ed. by Adam Makkai, Alan K. Melby. John Benjamins Publishing Company, pp. 3-11.

HEINE, B., REH, M. 1984. Grammaticalizationan Reanalysis in African Languages. Hamburg: Helmut Buske.

HÜLLEN, W. .1982. Verbs of Causativity in the English Interlanguage of German Learners. The Contrastive Grammar of English and German / Ed. by Walter F.W. Johnes and Edwin A. Hopkins. Karoma Publisher. Inc. Ann Arbor, Michigan, (1) pp. 170-177.

KAFKA, F. 1989. Beschreibung eines Kampfes. Novellen, Skizzen, Aphorismen aus dem Nachlass. Frankfurt am Main: Fischer Taschenbuch Verlag. $280 \mathrm{~S}$.

LAKOFF, G. - JOHNSON M. 2003. Metaphors We Live. University Of Chicago Press; 2nd edition. $256 \mathrm{p}$.

LAKOFF, G. 1990. Women, Fire, and Dangerous Things. What Categories Reveal about the Mind. Chikago, London: University of Chicago Press. 614 p.

LEHMANN, Chr. 1985. Grammaticalization: Synchronic variation and diachronic change. Lingua e Stile. 
MAISAK, T.A. 2005. The typology of grammaticalization of the structures with action and positional verbs. Moscow. 480 p.

MURYASOV, R.Z. 1989. Word-formation and the theory of nominalization. Voprosy jazykoznanija. \# 2. pp. 39-53.

New Trends in Linguistics. 1964. An orientation by Bertil Malmberg. Transl. from Swedish original by Edward Carney. University of Manchester. Stockholm, MLXIV. $226 \mathrm{p}$.

SILNITSKY, G.G. 2006. Semantics, Grammar. Quantitative and typological linguistics: in 2 volumes. Vol. I. Smolensk. 255 p.; Vol. 2. 362 p.

SYMULOV, M.G. 2006. Ways of expressing causative relations in different languages (based on English and the Chuvashi language). Cheboksary. 275 p.

SZCZEPANIAK, R. 2011. Grammatikalisierung im Deutschen. Eine Einführung. 2, Auflage. Tübingen: Narr Francke Attempto Verlag GmbH + Co.KG. 219 S.

SÜSKIND, P. 1994. Das Parfum. Die Geschichte eines Mörders. Zürich: Diogenes Verlag AG Zürich. 3203.

TRAUGOTT, E.C., HEINE, B. 1991. Introduction. Approaches to Grammaticalization: Volume II. Types of grammatical markers. Ed. E.C. Traugott, B. Heine. John Benjamins Publishing Company. pp. 1-14.

Words: 4127

Characters: $27271(15,15$ standard pages $)$

Professor of Advertising Svetlana V. Shustova, Doctor of Philology

Public Relations and Humanities Department,

Perm Institute of Economics and Finance,

141, Yekaterininskaya Str.

614000, Perm,

Russia

sciencescience108@yahoo.com

Senior lecturer Elena A. Osheva, PhD in Philology

English language department,

Institute of Foreign languages and Linguistic

Communication in Management, State University of Management,

Moscow

Russia

Associate Professor Konstantin A. Klochko, PhD in Philology

Advertising, Public Relations and Humanities Department

Perm Institute of Economics and Finance

141, Yekaterininskaya Str.

614000, Perm

Russia

41

XLinguae Journal, Volume 10 Issue 1, January 2017, ISSN 1337-8384 